\section{Indirect Hernia in Children}

Q.-Is it sufficient when dealing with a small indirect inguinal hernia in a child or young adult simply to excise the sac?

A.-For the great majority of such cases most surgeons regard simple excision of the sac as quite adequate. However, even in a child or young adult it is important to correct any stretching of the internal ring. Repair of the transversalis fascia is therefore important in any case in which there is a broad-necked sac with a large internal ring.

\section{Professional Secrecy in Evidence}

Q.-Is it still necessary to remind the judge of the absolute secrecy enjoined on a medical man when called as a witness in a case involving V.D. patients (Garner v. Garner, "Times Law Reports," 1919-20, 36, 196)? If so, has this formal protest to be lodged before being sworn in, and what wording would you recommend?

A.- Notwithstanding the rule of professional secrecy, a medical man has always had an overriding obligation to answer questions put to him in the witness box; the law in this respect has not changed. Nevertheless, if a medical witness is asked a question which, if answered, would in his opinion constitute a breach of professional confidence, it is desirable to remind a judge of the rule of professional secrecy observed by medical practitioners. This situation arises when the witness does not hold the consent of the patient to disclose information gained during his professional relationship with that patient. The right time to appeal to the judge is when a question is asked the answering of which would involve a breach of secrecy. The appeal might be in the following form: "My Lord, to answer this question would involve a breach of professional secrecy; am I compelled to answer it ?" Most practitioners accept the judge's ruling and follow his directions. There are some practitioners, however, who are so firmly attached to the ethical rule that they would rather accept imprisonment for contempt of court than disclose the secrets of their patients in the absence of consent.

\section{Catabolic Foods}

Q. - I have read that certain foods such as some vegetables are catabolic because they require energy for their absorption. Is this view correct?

A.- This statement is probably true, although not necessarily in relation to absorption. A drink of cold water is catabolic in the sense that a corresponding amount must be lost either as urine, at body temperature, or as sweat, which during drying will cool the body by the absorption of latent heat. Some vegetables, such as melons, radishes, and lettuce, provide only about 50 calories per $\mathrm{lb}$. (110 per $\mathrm{kg}$.). and if all their water were evaporated from the skin nearly 300 calories would be absorbed, either from the body or from the surrounding atmosphere. In hot weather, therefore, these vegetables may cool the body rather than warm it. We must not forget, however, that tortoises can keep going for years on a diet of nothing but lettuce.

\section{The Imperial Eunuchs}

Q.-Can you tell me the Chinese method of making eunuchs? How were they selected, and at what age were they castrated? What was the reason for their great influence in the imperial courts?

A.-Castration in China goes back, so it is said, to about 1100 B.C., although it did not become what perhaps can be called an official practice till much later. Persons permitted themselves to be made eunuchs either from necessity (when they were compelled to submit under threat of force) or through poverty or even through choice. The age at which the operation was performed varied from childhood up to about 25 or later, and the methods employed do not seem to have varied much, according to the reports that have been made available to us. It is said that sometimes a form of local analgesia was employed, but few details appear to be available. The method most usually adopted was to remove the whole of the external genitalia either with a sickle-shaped knife or by some other means. A plug was then inserted into the urethra and the wound covered in paper soaked in cold water. Healing was said to take place within about 100 days, and the mortality has been reported as being something like $4 \%$, or even less. The influence exercised by the imperial eunuchs was doubtless due to their knowledge of court intimacies and intrigues, and to the fact that they often acted as intermediaries between the emperor and his concubines.

\section{Will a Wig Stop Hair Growing ?}

Q.-Does the temporary use of a wig prejudice the regrowth of hair in a case of alopecia?

$$
\text { A.- The answer is no. }
$$

\section{NOTES AND COMMENTS}

Abortifacient Pastes.-Professor ANDrew M. Claye (University of Leeds) writes: I am interested in the reply in "Any Questions ?" (Journal, November 28, p. 1229) to the query on abortifacient pastes. The last sentence but one reads: "These pastes are neither as safe nor as efficient as is often stated, but it has to be remembered that the same can be said of nearly all methods for inducing abortion." From the use of the word "nearly" I infer that perhaps the writer knows some safe and efficient method. What is it ? I am glad to say that $I$ have no extensive experience of inducing abortion, but I have had enough to acquire a great dislike for the method of dilatation and curettage, partly because I have some fear of perforating the uterus, but even more because I am rarely certain that the uterus is empty when I have finished. In my experience, it is seldom that utus paste fails to produce expulsion of the uterus within 48 hours, and abortion is nearly always complete. From Mr. David Maxwell's remarks at the Royal Society of Medicine on November 27, I gather that his experience has been like mine.

OUR EXPERT writes: I agree with Professor Claye that the word " nearly" could with advantage have been omitted from the sentence mentioned. It is also true that many in this country have used abortifacient pastes with satisfactory results over several years. When this matter was previously a subject for a question and a cautious answer one doctor wrote to say how surprised he was to learn of the dangers of the method-having himself used it without ill effect for more than 10 years. Within one week of writing the letter, however, he encountered two fatal cases, and he was good enough to write again immediately and to report the full details of these cases. The post-mortem findings were of the kind indicated in the warning given in the original reply (see also "Any Questions?" August 23, 1947, p. 317).

Causes of Failure of Contraceptive Diaphragms.-MariB Stopes, D.Sc. (London, W.1) writes: May I add to your reply ("Any Questions?" November 28, p. 1229) about the fantastic failure rate of three in twenty? It suggests in addition to the six possible causes you give another also-that is, trust in a jelly instead of a grease. As the essential supplement to a diaphragm cap there is no contraceptive jelly in the world which can be relied on to give approximately $100 \%$ security, but a lowmelting-point grease does give this.

Correction.- In the obituary notice of Dr. K. E. Eckenstein (Journal, September 12, p. 630) we were in error in saying that he was born in Alsace; he was, in fact, born in Liverpool.

All communications with regard to editorial business should be addressed to THE EDITOR, British MEdical Journal, B M.A. House, Tavistoc SQUARE. LONDON, W.C.1. TrLePHONE: EUSTON 4499. TELEORAMS Aitiology, Westcent, London. ORIGINAL ARTICLES AND LETTERS forwarded for publication are understood to be offer Medical Journal alone unless the contrary be stated.

Authors desiring REPRINTS should communicate with the Publishin: Manager, B.M.A. House, Tavistock Square, W.C.1. on receipt of proofs Authors overseas should indicate on MSS. if reprints are required, as proofs are not sent abroad.

ADVERTISEMENTS should be addressed to the Advertisement Manager. B.M.A. House, Tavistock Square, London, W.C.1 (hours 9 a.m. to 5 p.m.). TELEPHONE: EUSTON 4499. TELEGRAMS: Britmedads. Westcent. London.

MEMBERS' SUBSCRIPTIONS should be sent to the SECRETARY of the Association. Telephone: EUSTON 4499. TElegrams: Medisecra,

B.M.A. ScotTISH OFFICE: 7, Drumsheugh Gardens, Edinburgh. 